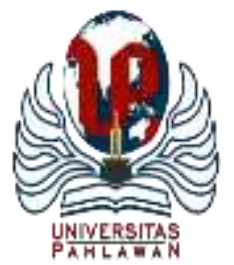

Edukatif : Jurnal Ilmu Pendidikan Volume 3 Nomor 6 Tahun 2021 Halm 4858 - 4864

EDUKATIF: JURNAL ILMU PENDIDIKAN

Research \& Learning in Education

https:/ledukatif.org/index.php/edukatif/index

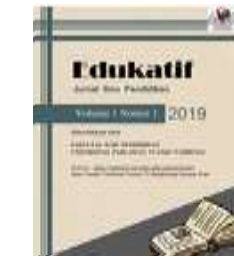

\title{
Efektivitas Penggunaaan Metode Direct Instruction untuk Meningkatkan Keterampilan Melukis Henna Pengantin pada Anak Tunarungu Di SLB
}

\author{
Dayang Sagita Ligusti ${ }^{1 凶}$, Damri Damri \\ Universitas Negeri Padang, Indonesia ${ }^{1,2}$ \\ E-mail : damrirajomdn18@gmail.com ${ }^{1}$, sagitadayang@gmail.com ${ }^{2}$
}

\begin{abstract}
Abstrak
Penelitian berisikan tentang keterampilan melukis henna pengantin untuk siswa tunarungu dengan menggunakan metode Direct Instruction. Tujuannya membuktikan keefektifan metode metode Direct Instruction dalam upaya meningkatkan keterampilan melukis henna pengantin untuk anak tunarungu di SLB. Penelitian ini menggunakan metode eksperimen dalam bentuk pre-eksperimental dengan jenis one group pretest-postest design. Subjek dalam penelitian ini yaitu lima siswa tunarungu. Untuk menentukan kondisi awal, peneliti melakukan pretest, kemudian treatment menggunakan metode Direct Instruction diakhiri dengan melakukan posttest, kemudian data yang diperoleh diolah dengan uji Wilcoxon Rank Tast. Dari data yang telah dikumpulkan diperolehlah rata-rata pretest 43,40 dan hasil posttest ialah 88,60 dimana hasil tersebut mengalami peningkatan. Pengolahan data dilakukan dengan memakai uji wilcoxon dengan hasil rank tast antara pretest dan posttest 2,070 dengan Asymp. Sig (2-tailed) 0,038. Probabilitas yang ditetapkan ialah $\alpha$ $=0,05$. Hipotesis alternatif diterima karena probabilitas < dari probabilitas yang telah ditetapkan yakni 0,038 $<0,05$. Hal tersebut membuktikan metode Direct Instruction efektif dalam meningkatkan keterampilan melukis henna pengantin bagi anak tunarungu .
\end{abstract}

Kata Kunci: Metode Direct Instruction, Keterampilan Melukis Henna Pengantin, Siswa Tunarungu

\begin{abstract}
The research contains the skills of bridal henna painting for deaf students using the Direct Instruction method. The goal is to prove the effectiveness of the Direct Instruction method to improve bridal henna painting skills for deaf children at SLB. This study uses an experimental method in the form of preexperimental with the type of one-group pretest-posttest design. The subjects in this study were five deaf students. To determine the initial conditions, the researcher conducted a pretest, then the treatment using the Direct Instruction method ended with a posttest, then the data obtained was processed by the Wilcoxon Rank Test. From the data that has been collected, the average pretest is 43.40 and the posttest result is 88.60 where the results have increased. Data processing was carried out using the Wilcoxon test with the results of the rank test between the pretest and posttest being 2,070 with Asymp. Sig (2-tailed) 0.038. The set probability is $=0.05$. The alternative hypothesis is accepted because the probability $<$ from the predefined probability is $0.038<0.05$. This proves that the Direct Instruction method is effective in improving bridal henna painting skills for deaf children.
\end{abstract}

Keywords: Direct Instruction Method, Bridal Henna Painting Skills, Deaf Students

Copyright (c) 2021 Dayang Sagita Ligusti, Damri Damri

$\triangle$ Corresponding author:

Email : damrirajomdn18@gmail.com

DOI $\quad$ : https://doi.org/10.31004/edukatif.v3i6.1579

ISSN 2656-8063 (Media Cetak)

ISSN 2656-8071 (Media Online)

Edukatif : Jurnal Ilmu Pendidikan Vol 3 No 6 Tahun 2021 p-ISSN 2656-8063 e-ISSN 2656-8071 
4859 Efektivitas Penggunaaan Metode Direct Instruction untuk Meningkatkan Keterampilan Melukis Henna Pengantin pada Anak Tunarungu Di SLB - Dayang Sagita Ligusti, Damri Damri

DOI: https://doi.org/10.31004/edukatif.v3i6.1579

\section{PENDAHULUAN}

Pendidikan adalah hal yang penting bagi setiap individu. Adanya pendidikan membuat seseorang menjadi pribadi yang terdidik dan berguna bagi bangsa, negara dan agama. Dalam dunia pendidikan seorang siswa tidak hanya di nilai dari kemampuan intelektualnya, tetapi juga dari sikap dan keterampilan yang dimilikinya. Pendidikan diberikan kepada setiap anak, termasuk anak berkebutuhan khusus.

Anak berkebutuhan khusus ialah mereka yang memerlukan penanganan khusus karena mengalami gangguan dari berbagai aspek, baik itu fisik maupun psikologis (Ratrie Desningrum, 2007). Anak berkebutuhanan khusus merupakan istilah yang digunakan untuk menyebut individu dengan karakteristik tertentu seperti kelainan pada fisik, mental, emosi, sosial, atau gabungan dari beberapa kelainan. (Simorangkir, 2019). Maka dari itu, untuk membantu mereka dari berbagai hambatan tersebut, diperlukan pendidikan yang sesuai dengan jenis, jenjang, dan kebutuhannya agar tidak tertinggal jauh dengan anak-anak normal lainnya, serta dapat menempatkan diri di tengah masyarakat termasuk anak tunarungu.

Tunarungu merupakan kondisi dimana seseorang mengalami hambatan atau gangguan dengan indra pendengarannya sehingga komunikasi tidak berjalan dengan lancar. Menurut (Wasito et al., 2012) tunarungu ialah anak yang mengalami kekurangan atau bahkan kehilangan kemampuan dalam mendengar dikarenakan kerusakan pada indra pendengarannya. Sedangkan menurut (Gunawan, 2016) tunarungu ialah seseorang yang maengalmi kehilangan pendengaran baik secara keseluruhan atau sebagaian daya dengarnya. Kemudian sejalan dengan itu, (Rahmah, 2018) mengatakan bahwa untuk melatih sisa-sisa pendengaran anak tunarungu perlu diberikan rangsangan berupa bunyi-bunyian, dan dapat juga diberikan pertolongan dengan alat bantu dengar. Anak tunarungu dalam melakukan komunikasi dengan orang lain lebih sering menggunakan isyarat tubuh, sehingga komunikasi yang terjadi seringkali hanya berjalan satu arah. Meskipun anak Tunarungu mempunyai masalah dalam pendengarannya, tetapi mereka juga memerlukan keterampilan sebagai penunjang kehidupan untuk memenuhi kebutuhan hidupnya. (Marlina, 2021).

Keterampilan merupakan kemampuan seseorang dalam menciptakan, mengolah, dan menyelesaikan suatu pekerjaan dengan terampil. Keterampilan sudah ada dalam diri manusia semenjak ia dilahirkan, namun keterampilan yang dimiliki harus terus menerus diasah dan dikembangkan melalui proses belajar. Menurut (Damri et al., 2017) rendahnya kemampuan yang dimiliki anak tidak menghambat keberhasilan anak dalam mengembangkan kemampuannya jika memiliki keyakinan atas apa yang dilakukannya. Sejalan dengan itu, (Jaya, 2017) mengatakan bahwa pendidikan keterampilan adalah program pilihan yang dapat diberikan kepada peserta didik dengan mengarahkan penguasaan pada satu jenis keterampilan atau lebih yang kemudian dapat digunakan untuk mendapatkan penghasilan. Oleh sebab itu disni peran guru sangat penting dalam mengajarkan ketarampilan voksional yang nantinya dapat berguna bagi para siswanya.

Salah satu dalam pembelajaran keterampilan yang ada dalam kurikulum ialah pembelajaran seni lukis. Seni lukis yang dapat diajarkan kepada anak tunarungu ialah melukis henna penganten. Menurut (Putri et al., 2017) memakai henna menjadi tradisi ritual pernikahan dengan menghias tangan dan kaki bakal calon pengantin. Tangan dan kaki calon pengantin akan diwarnai dengan membentuk motiv dan corak yang menarik menggunakan henna. Tidak hanya itu, penggunaan henna juga terdapat pada acara atau hari-hari besar seperti pada saaat Idul Fitri, Idul Adha dan Maulid Nabi yang digunakan oleh wanita dan anak-anak (Hasma, 2018). Pemakaian henna pada calon pengantin merupakan acara yang sangat sakral dengan tujuan menjaga calon pengantin dari kejahatan baik yang terlihat maupun tidak, (Oktora \& Amsia, 2017). Untuk itu, seni lukis henna pengantin ini perlu diajarkan kepada anak tunarungu dengan tujuan membekalinya dengan suatu keterampilan yang dikemudian hari.

Berdasarkan hasil observasi di SLB Negeri 2 Padang, ditemukan lima siswa tunarungu. Tiga orang siswa kelas $\mathrm{X}$ dan 2 orang kelas XI. Terkait dengan kemampuan akademiknya, mereka mampu mengikuti pembelajaran dengan memenuhi nilai ketuntatasan minimum. Begitupun pada pembelajaran keterampilan 
4860 Efektivitas Penggunaaan Metode Direct Instruction untuk Meningkatkan Keterampilan Melukis Henna Pengantin pada Anak Tunarungu Di SLB - Dayang Sagita Ligusti, Damri Damri

DOI: https://doi.org/10.31004/edukatif.v3i6.1579

yang mereka ikuti, khusunya pada pembelajaran seni lukis, mereka telah menghasilkan banyak karya bernilai seni. Seperti melukis pada kanvas, kain, dan dinding. Dari berbagai karya tersebut, diketahui bahwa mereka belum pernah belajar mengenai seni lukis henna pengantin.

Berdasarkan hasil wawancara, guru menyatakan bahwa belum pernah mengajarkan keterampilan melukis henna pengantin kepada peserta didik, dikarenakan tidak begitu memahami cara melukis henna pengantin. Guru juga tidak menyediakan alat dan bahan yang menunjang proses pembelajaran melukis henna pengantin. Diketahui bahwa guru telah mengajarkan seni lukis menggunakan metode demonstrasi. Menurut (Rifai, 2017) demonstrasi adalah pembelajaran yang dilakukan dengan cara mempraktekan kepada peserta didik mengenai suatu proses yang sedang dipelajari. Sedangkan menurut (Gafur, 2018) metode demonstrasi merupakan cara guru mengejar dengan memperagakan suatu kegiatan diiringi dengan penjelasan secara lisan. Dalam prakteknya yang terjadi di sekolah tersebut, apabila guru menemui kendala dalam menyampaikan materi, maka beliau akan meminta bantuan guru kelas untuk menjelaskan lebih lanjut kepada peserta didik. Sehingga pembelajaran menjadi kurang efektif.

Berhubungan dengan permasalahan tersebut, peneliti mencoba memberikan model pembelajaran yang berbeda dari sebelumnya yaitu dengan menggunakan metode direct instruction. Menurut (Zahriani, 2014) Direct Instruction merupakan pembelajaran modelling, dimana guru berperan sebagai model untuk membimbing para peserta didiknya dalam mempelajari pengetahuan yang berhubungan dengan pengetahuan dan konsep. Sejalan dengan itu, (Rakhman, 2017) menyatakan bahwa Direct Instruction memberikan siswa latihan melalui dua tahap, yaitu tahapan latihan terbimbing dan latihan mandiri. Pelatihan terbimbing akan menjadikan peserta didik lebih paham dan terarah mengenai materi yang diberikan melalui arahan yang diberikan oleh guru. Kemudian dengan latihan mandiri diharapkan peserta didik lebih mudah memahami materi karena sebelumnya telah dilakukan pelatihan terbimbing. Jadi metode direct instruction merupakan metode pembelajaran dengan memberikan instruksi langsung kepada peserta didik baik perseorangan ataupun berkelompok. Direct Instruction memberikan pembelajaran yang menuntun peserta didik dalam mempelajari materi yang bersifat prosedural dan dapat diajarkan secara terstruktur langkah demi langkah.

Selanjutnya penulis melakukan test kepada ke lima anak tersebut. Tes ialah lembar instrumen yang berisikan butir-butir soal untuk mengukur pengetahuan, bakat, dan keterampilan, (Aisyah, 2018). Dari hasil tersebut di dapatkan hasilnya bahwa ke lima anak tersebut masih belum mampu melukis henna pengantin, yang dapat dilihat dari butir-butir test yang diberikan berupa: menggunting ujung conne henna, cara memegang conne henna, membuat garis vertikal dan horizontal, dan membuat motif dasar menghenna. Secara keseluruhan mereka belum mampu menggunting conne henna dengan benar, conne henna yang digunting menghasilkan lubang yang terlalu besar. Begitupun dengan cara mereka memegang conne henna yang tidak tepat, sehingga garis yang dibuat menjadi putus-putus dan menghasilkan henna yang kurang rapi. Hal itu wajar terjadi karena sebelumnya peserta didik belum pernah mencoba melakukannya.

\section{METODE}

Peneliti memakai jenis penelitian eksperimen. Adapun menurut (Margono, 2014) penelitian eksperimen ialah suatu percobaan yang dirancang secara khusus untuk menimbulkan data yang diperlukan guna menjawab pertanyaan-pertanyaan penelitian. Sejalan dengan itu (Emzir, 2009) menyatakan bahwa penelitian eksperimen merupakan jenis penelitian yang paling banyak digunakan dan juga penelitian yang paling produkti. Jenis penelitian yang digunakan yaitu Pre-eksperimental design dengan bentuk One Group Pretest- Posttest Design. Peneliti akan membandingkan hasil perlakuan yang diberikan dengan keadaan sebelum diberikan perlakuan. Metode penelitian eksperimen rancangan Pre-eksperimental design dengan bentuk One Group Pretest- Posttest Design ini terdapat pretest yaitu suatu kondisi sebelum diberikan perlakuan, kemudian diberikan suatu perlakuan. Perlakuan yang diberikan kepada kelompok eksperimen disini ialah penggunaan 
4861 Efektivitas Penggunaaan Metode Direct Instruction untuk Meningkatkan Keterampilan Melukis Henna Pengantin pada Anak Tunarungu Di SLB - Dayang Sagita Ligusti, Damri Damri

DOI: https://doi.org/10.31004/edukatif.v3i6.1579

metode Direct Instruction untuk mengajarkan melukis henna pengantin, kemudian langkah terakhir akan dilakukan posttest yaitu penilaian akhir ada atau tidaknya pengaruh treatmen terhadap kelompok tersebut.

Menurut (Sugiyono, 2017), penelitian eksperimen dengan rancangan Pre-eksperimental dengan bentuk One Group Pretest- Posttest Design digambarkan sebagai berikut:

\section{$\mathrm{O}_{1} \mathrm{X} \mathrm{O}_{2}$}

\section{Gambar 1. Rancangan Penelitian Pre-eksperimental One Group Pretest- Posttest Design}

Keterangan:

$\mathrm{O}_{1}=$ Pretest, yaitu nilai awal anak sebelum diajarkan keterampilan melukis henna pengantin menggunakan metode Direct Instruction (observasi 1)

$\mathrm{X}=$ Treatment (perlakuan), memberikan perlakuan kepada objek penelitian, yaitu berupa penggunaan metode Direct Instruction dalam mengajarkan keterampilan melukis henna pengantin

$\mathrm{O}_{2}=$ Posttest, yaitu nilai akhir atau hasil yang didapatkan siswa dalam melukis henna pengantin setelah diberikan treatment berupa metode Direct Instruction.

\section{HASIL DAN PEMBAHASAN PENELITIAN}

Metode yang dipilih yaitu Pre-eksperimen design dengan jenis one group pretest-postest design. Penelitian ini dilaksanakan terhadap satu kelompok eksperimen tanpa kelompok pembanding pada saat dilakukan tes pada subjek. Berikut hasil olah data dalam penelitian ini:

1. Berikut data perolehan nilai pretest dan posttest siswa:

Tabel 1

Nilai pretest dan posttest

\begin{tabular}{|c|c|c|c|}
\hline No & Subjek & Pretest & Posttest \\
\hline 1. & ME & 41 & 88 \\
\hline 2. & I & 47 & 91 \\
\hline 3. & $\mathrm{~T}$ & 44 & 88 \\
\hline 4. & $\mathrm{AL}$ & 47 & 91 \\
\hline 5. & AN & 38 & 85 \\
\hline & JUMLAH & 217 & 443 \\
\hline
\end{tabular}

2. Data Hasil Pretest

Tabel 2

Descriptive Stastics Pretest

\begin{tabular}{|c|c|c|c|c|c|}
\hline & $\mathrm{N}$ & Minimal & Maksimal & Mean & Std. Deviation \\
\hline Pretest & 5 & 38 & 47 & 43,40 & 3,912 \\
\hline Valid N (listwise) & 5 & & & & \\
\hline
\end{tabular}

Dari tabel 2, diketahui hasil tertinggi pada pretest adalah 47 sedangkan hasil terendahnya ialah 38 dan rata-ratanya ialah 43,40 .

3. Data Nilai Postest

Tabel 3

Descriptive Stastics Posttest

\begin{tabular}{lrrrrr}
\hline & N & Minimal & Maksimal & Mean & Std. Deviation \\
\hline Posttest & 5 & 85 & 91 & 88.60 & 2,510 \\
\hline Valid N (listwise) & 5 & & & & \\
\hline
\end{tabular}

Dari tabel 3, diketahui hasil tertinggi dari posttest ialah 91 dan hasil terendahnya 85. Hasil rata-rata dari posttest adalah 88,60. 
4862 Efektivitas Penggunaaan Metode Direct Instruction untuk Meningkatkan Keterampilan Melukis Henna Pengantin pada Anak Tunarungu Di SLB - Dayang Sagita Ligusti, Damri Damri

DOI: https://doi.org/10.31004/edukatif.v3i6.1579

4. Pengujian hipotesis

Tabel 4

Pengujian Hipotesis

\begin{tabular}{|c|c|c|c|}
\hline Hipotesis & $\begin{array}{l}\text { Asymp. } \\
\text { (2-tailed) }\end{array}$ & $\begin{array}{l}\text { Sig.Taraf } \\
\text { signifikansi (a) }\end{array}$ & Kesimpulan \\
\hline $\begin{array}{l}\text { Ho: } \\
\text { Metode Direct Instruction tidak efektif } \\
\text { digunakan dalam kegiatan melukis henna } \\
\text { pengantin. }\end{array}$ & $>0.05$ & 0.05 & Ho terima \\
\hline $\begin{array}{l}\text { Ha: } \\
\text { Metode Direct Instruction efektif } \\
\text { digunakan untuk kegiatan melukis henna } \\
\text { pengantin }\end{array}$ & $<0.05$ & 0.05 & Ha diterima \\
\hline
\end{tabular}

Membuktikan Metode Direct Instruction efektif dalam meningkatkan keterampilan melukis henna pengantin, maka dilakukanlah uji analisis wilcoxon sign Rank test dengan hasil:

5. Hasil Uji Analisis

Tabel 5

Test Stastics

\begin{tabular}{lrr}
\hline & posttest - pretest \\
\hline$Z$ & $-2,70^{\mathrm{b}}$ \\
\hline Asymp. Sig. (2-tailed) & 0,038 \\
\hline
\end{tabular}

a. Wilcoxon Signed Ranks Test

b. Based on negative ranks.

Dari test yang telah dilakukan diperoleh hasil pretest dan posttest 2,070 dengan probabilitas atau Asymp Sig (2-tailed) 0,038. Nilai probabilitas yang telah didapat akan dibandingkan dengan probabilitas yang telah ditetapkan $\alpha=0.05$, Maka diperoleh hasil $(0.038<0.05)$. Jadi hasil analisis deskriptif diperoleh rata-rata pretest 43,40 dan posttest 88,60 , hal itu membuktikan metode Direct Instruction efektif dalam meningkatkan keterampilan melukis henna pengantin bagi siswa tunarungu di SLB N 2 Padang.

\section{Pembahasan}

Pembahasan ini terfokus pada efektivitas penggunaan metode Direct Instruction dalam meningkatkan keterampilan melukis henna pengantin untuk anak tunarungu di SLB N 2 Padang. Pada latar belakang masalah telah dipaparkan bahwa subjek penelitian ini berjumlah lima orang siswa yang sebelumnya belum pernah melakukan pembelajaran mengenai melukis henna pengantin ini.

Penelitian ini diawali dengan memberikan tes awal (Pretest) yang dilaksanakan sebanyak satu kali pertemuan selama kurang lebih satu jam dan kemudian diperoleh hasil 43,40 Selanjutnya peneliti melakukan pemberian treatment berupa penggunaan metode Direct Instruction yang dilakukan sebanyak lima kali pertemuan. Langkah terakhir yaitu dilakukan posttest untuk melihat sejauh mana kemampuan anak setelah diberikan perlakuan, adapun hasil yang diperoleh pada posttest ialah 88,60.

Penelitian ini menggunakan metode Direct Instruction dengan tujuan meningkatkan keterampilan melukis henna pengantin bagi anak tunarungu. Hasil dari pembelajaran ini terlihat meningkat jika dilihat dari pretest dan posttest. Dibuktikan melalui uji wilcoxon sign rank test dimana 2.070 dan asymp sig. (2-tailed) = 0.038, berarti nilai $\alpha>$ Asymp sig. (2-tailed) dengan demikian Ha diterima dan Ho ditolak.

Penelitian ini relevan dengan penelitian (Rakhman, 2017) yang menyatakan bahwa hasil belajar siswa pada mata pelajaran gambar teknik meningkat dengan menggunakan metode pembelajaran direct instruction. Selanjutnya berdasarkan penelitian (Sofiyah (UIN Syarif Hidayatullah Jakarta), 2010) mengenai pengaruh model pengajaran langsung (direct instruction) terhadap hasil belajar fisika siswa. Menunjukkan bahwa terdapat pengaruh yang signifikan pada penggunaan model pembelajaran direct instruction terhadap hasil 
4863 Efektivitas Penggunaaan Metode Direct Instruction untuk Meningkatkan Keterampilan Melukis Henna Pengantin pada Anak Tunarungu Di SLB - Dayang Sagita Ligusti, Damri Damri

DOI: https://doi.org/10.31004/edukatif.v3i6.1579

belajar fisika siswa. Berdasarkan penelitian sebelumnya, dapat dinyatakan bahwa penelitian yang telah peneliti lakukan menunjukkan keefektifan penggunaan metode direct instruction dalam bidang vokasional khususnya seni lukis. Dengan begitu metode ini dapat digunakan oleh guru dalam menunjang proses pembelajaran.

\section{KESIMPULAN}

Penelitian ini dilakukan di SLB N 2 Padang dengan tujuan membuktikan efektivitas metode direct instruction untuk meningkatkan keterampilan melukis henna pengantin untuk anak tunarungu. Berdasarkan hasil penelitian dan pembahasan, maka dapat ditarik kesimpulan bahwa penggunaan metode direct instruction efektif dalam meningkatkan keterampilan melukis henna pengantin untuk anak tunarungu di SLB N 2 Padang.

Hal ini dapat dilihat dari hasil perhitungan data yang diperoleh selama menjalankan penelitian yang diuji dengan menggunakan Wilcoxon sign rank test.

\section{DAFTAR PUSTAKA}

Aisyah, S. N. dkk. (2018). Instrumen Penelitian Dan Teknik Pengumpulan Data. Journal of Chemical Information and Modeling, 53(9), 1689-1699.

Damri, D., Engkizar, E., \& Anwar, F. (2017). Hubungan Self-Efficacy Dan Prokrastinasi Akademik Mahasiswa Dalam Menyelesaikan Tugas Perkuliahan. JURNAL EDUKASI: Jurnal Bimbingan Konseling, 3(1), 74. https://doi.org/10.22373/je.v3i1.1415

Emzir. (2009). metodologi penelitian kuantitatif \& kualitatif. Raja Grafindo Persada.

Gafur, A. (2018). Peningkatan Hasil Belajar IPA Terpadu Melalui Metode Demonstrasi Pada Siswa Kelas VIII SMP Negeri 2 Sano Nggoang Manggarai Barat Tahun Pelajaran 2017/2018. Jisip, 2(1), 144-161.

Gunawan, D. (2016). Modul Guru Pembelajar SLB Tunarungu Kelompok Kompetensi A. Bandung. PPPPTK TK dan PLB.

Hasma, A. (2018). Skripsi Studi pada Komunitas “ Makassar Henna Artist .” Universitas Negeri Makassar.

Jaya, H. (2017). keterampilan vokasional bagi anak berkebutuhan khusus perwatan dan perbaikan alat elektronika. Fakultas MIPA Universitas Negeri Makassar: Makasar.

Margono. (2014). Metodologi Penelitian Pendidikan. PT. Asdi Mahasatya.

Marlina, W. P. R. M. (2021). Efektivitas Model Pembelajaran Procedural dalam Meningkatkan Keterampilan Vokasional bagi Siswa Tunarungu di Sekolah Luar Biasa.

Oktora, D. R., \& Amsia, T. (2017). Tradisi Malam Bainai pada Acara Perkawinan Adat Padang Pariaman di Kecamatan Rajabasa Kota Bandar Lampung. FKIP Universitas Lampung, 01, 1-13. http://digilib.unila.ac.id/27753/10/Skripsi Tanpa Bab Pembahasan.pdf

Putri, N. S., Dewi, R., Studi, P., Vokasional, P., Keluarga, K., Syiah, U., Darussalam, K., Aceh, B., Berinai, T., \& Inai, M. (2017). Proses Upacara Berinai pada Pengantin di Desa. 2(November), 42-57.

Rahmah, F. N. (2018). Problematika Anak Tunarungu Dan Cara Mengatasinya. Quality, 6(1), 1. https://doi.org/10.21043/quality.v6i1.5744

Rakhman, A. (2017a). Penggunaan Model Pembelajaran Direct Instruction Untuk Meningkatkan Hasil Mata Pelajaran Gambar Teknik Kelas X Smk Negeri 1 Kedungwuni.

Rakhman, A. (2017b). Penggunaan Model Pembelajaran Direct Instruction untuk Meningkatkan Hasil Mata Pelajaran Gambar Teknik Kelas X SMK Negeri 1 Kedungwuni.

Ratrie Desningrum, D. (2007). Psikologi Anak Berkebutuhan Khusus. Depdiknas, 1-149.

Rifai, R. (2017). Penerapan Metode Demonstrasi untuk Meningkatkan Hasil Belajar Pendidikan Agama Kristen Materi Pembelajaran Sakramen Perjamuan Kudus VIII SMP Negeri 17 Surakarta, Tahun 
4864 Efektivitas Penggunaaan Metode Direct Instruction untuk Meningkatkan Keterampilan Melukis Henna Pengantin pada Anak Tunarungu Di SLB - Dayang Sagita Ligusti, Damri Damri

DOI: https://doi.org/10.31004/edukatif.v3i6.1579

2015/2016. DUNAMIS: Jurnal Penelitian Teologi Dan Pendidikan Kristiani, 1(2), 171.

https://doi.org/10.30648/dun.v1i2.112

Simorangkir, M. (2019). belantara anak berkebutuhan khusus. UKI Press.

Sofiyah (UIN Syarif Hidayatullah Jakarta). (2010). Pengaruh Model Pengajaran Langsung (Direct Instruction) Terhadap Hasil Belajar Fisika Siswa. 26.

Sugiyono. (2017). Metode Penelitian Pendidikan Pendekatan Kuntitatif, Kualitatif, dan R\&D. ALFABETA.

Wasito, D. R., Sarwindah, D., \& Sulistiani, W. (2012). Penyesuaian Sosial Siswa Tuna Rungu di Sekolah Umum. Jurnal Psikologi Teori Dan Terapan, 2(2), 81. https://doi.org/10.26740/jptt.v2n2.p81-92

Zahriani, Z. (2014). Kontektualisasi Direct Instruction Dalam Pembelajaran Sains. Lantanida Journal, 2(1), 95. https://doi.org/10.22373/lj.v2i1.667 